九州大学学術情報リポジトリ

Kyushu University Institutional Repository

\title{
Study on Reducing Raw Milk Transportation Cost in Taiwanese Dairy Industry
}

Lin, Lily

Department of Agricultural Economics, Faculty of Agriculture, Kyushu University

Kawaguchi, Tsunemasa

Department of Agricultural Economics, Faculty of Agriculture, Kyushu University

https://doi.org/10.5109/24271

出版情報：九州大学大学院農学研究院紀要. 43 (1/2)，pp.269-280，1998-11. Kyushu University バージョン：

権利関係 : 


\title{
Study on Reducing Raw Milk Transportation Cost in Taiwanese Dairy Industry
}

\author{
Lily Lin and Tsunemasa Kawaguchi
}

\author{
Department of Agricultural Economics, Faculty of Agriculture \\ Kyushu Liniversity, Fukuoka $812-8581$, Japan \\ (Received June 18, 1998 and accepted August 7, 1998)
}

\begin{abstract}
The production cost of milk products in Taiwan is higher than most coumtries like Anterica, New Zealand, Australia, and European countries. The main reason is that the scale of dairy farming is too small to save the labor cost and other raw milk producing costs in Taiwan. Moreover, the marketing costs including shipping, handling cost (between farms and factories as well as between factories and consumers) and company's other marketing cost are major part of tolal costs. In this paper, we would like to determine optimum routes to minimize the transportation cost of raw milk between dairy farms and factories under the assumption of fixed supply and demand. We conclude that under the condition of least cost routes of classical transportation problem, we can save around 10 percent of transportation cost. Then we consider the difficulty which we face to when we try to realize the least cost route under current factory demand and area supply of raw milk in practice. Finally, we would like to consider some appropriate policy to make factorics (dairy companies) cooperate with dairy farmers in order to reach the goal of least. Lransportation cost.
\end{abstract}

\section{INTRODUCTION}

Dairy farms and factories (plants) in Taiwan are located in 14 different counties (Hsien) as shown in figure 1. The proportion of farms' raw milk producing quantity in North, Middle, South and East of Taiwan is 15\%, 30\%, 52\%, and 3\% respectively. However, the proportion of plants' raw milk processing quantity in North, Middle, South and East of Taiwan is $37 \%, 33.6 \%, 27.6 \%$, and $1.6 \%$ respectively as in table 1 . The east part of Taiwan is currently a region of self-support and self-sufficiency due to the inconvenience of transportation as well as the scarcity of population. However, comparing with westem part, eastem part has not only a suitable weather, but also cheaper lands. There may be another possibility to utilize the foothills for dairy farms in eastern part. According to the above figures, this kind of unbalanced distribution between dairy farms and factories causes high transportation costs and makes raw milk easily spoiled. As the figure 1 indicates, the milk consumption (raw milk equivalent) concentrated on the north and middle of Taiwan. There must be another unbalanced distribution between factories and consumers (stores), so it is a possible topic for our next research.

As table 1 of present situation of delivering raw milk, there are 14 counties (Hsien) of raw milk supply as well as 33 factories (belonging to 29 companies) in Taiwan in the year of 1996. The biggest three companies which owns two or three factories each have 67 percent share of total raw milk processing quantity. They do not set up fixed raw milk processing quantity for each factory (as table 1 indicates, from factory 1 to factory 7), because they adjust the processing quantity among those two or three factories 
(1)

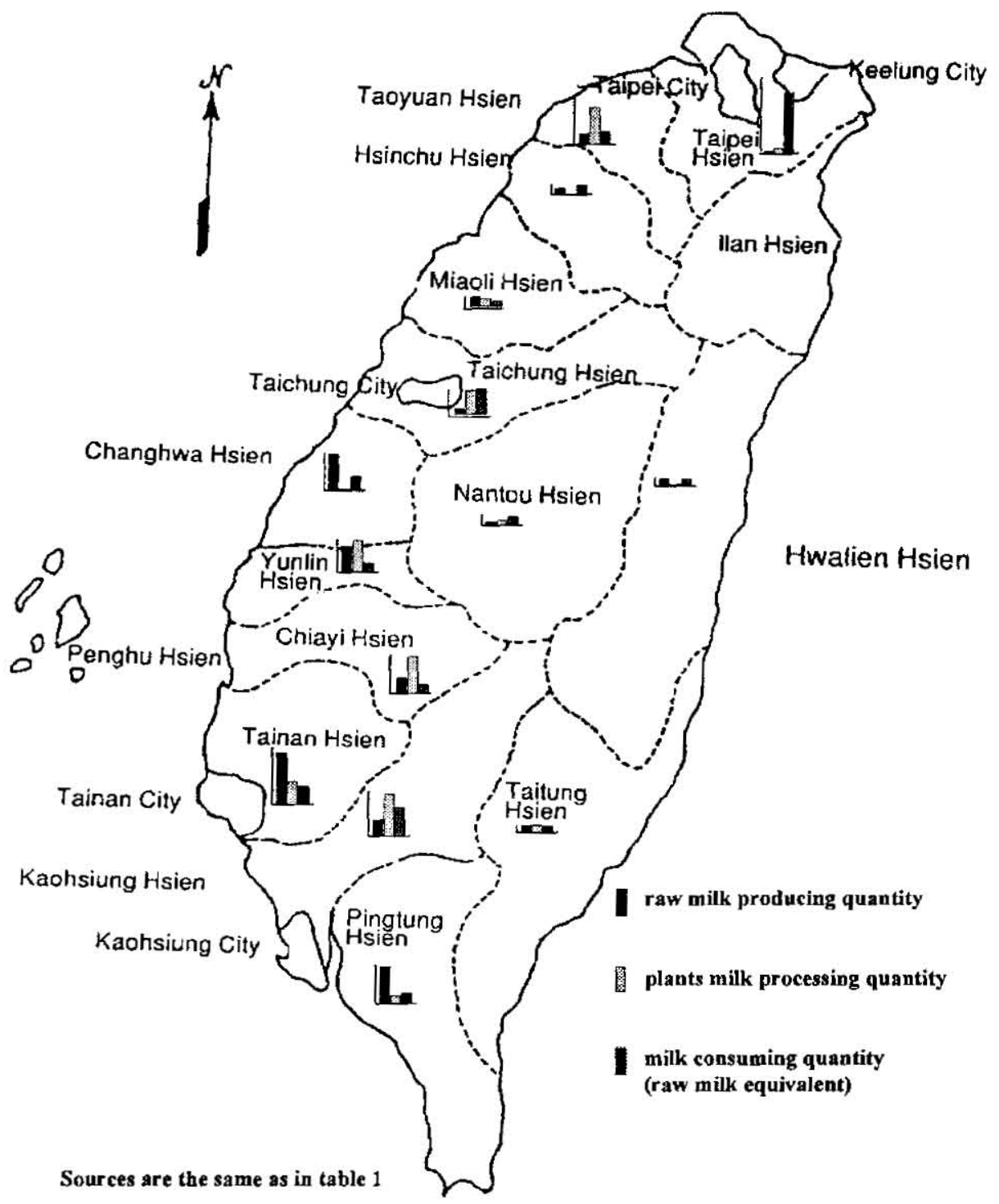

Fig. 1. Regional distributions of raw milk producing quantity, plants milk processing quantity, and milk consuming quantity (raw milk equivalent) in Taiwan in 1996 
Table 1. Raw milk shipment quantity from each supply area to each factory in 1996

\begin{tabular}{|c|c|c|c|c|c|c|c|c|c|c|c|c|c|c|c|c|c|}
\hline \multicolumn{18}{|c|}{ Unit: ton } \\
\hline Factory & $\begin{array}{l}1^{*} \\
1^{b}\end{array}$ & $\begin{array}{l}2 \\
8\end{array}$ & $\begin{array}{c}3 \\
11\end{array}$ & $\begin{array}{l}4 \\
2\end{array}$ & $\begin{array}{c}5 \\
10\end{array}$ & $\begin{array}{l}6 \\
2\end{array}$ & $\begin{array}{l}7 \\
9\end{array}$ & $\begin{array}{l}8 \\
2\end{array}$ & $\begin{array}{l}9 \\
5\end{array}$ & $\begin{array}{c}10 \\
4\end{array}$ & $\begin{array}{c}11 \\
5\end{array}$ & $\begin{array}{c}12 \\
5\end{array}$ & $\begin{array}{c}13 \\
2\end{array}$ & $\begin{array}{l}14 \\
2\end{array}$ & $\begin{array}{l}15 \\
11\end{array}$ & $\begin{array}{l}\mathbf{1 6} \\
13\end{array}$ & $\begin{array}{c}17 \\
5\end{array}$ \\
\hline $\begin{array}{ll}\text { 1 } & \text { Taipel } \\
2 & \text { Taoyuan } \\
3 & \text { Hsinchu } \\
4 & \text { Miaoli } \\
\text { 3) } & \text { Taichung } \\
6 & \text { Changhwa } \\
7 & \text { Nantou } \\
8 & \text { Yimlin } \\
9 & \text { Chiayi } \\
\text { 10 } & \text { Tainan } \\
\text { 11 Kaohsiung } \\
\text { 12 } \text { Piugtung } \\
\text { 1:3 Taitung } \\
\text { 14 } \text { Hwalien }\end{array}$ & $\begin{array}{r}24,040 \\
8,873\end{array}$ & 11,260 & 34,908 & $\left\{\begin{array}{r}631 \\
11,223 \\
1,184 \\
7,1353\end{array}\right.$ & $\begin{array}{r}26,394 \\
96.5 \\
592 \\
4,426 \\
4,4\end{array}$ & $\begin{array}{r}1,602 \\
16,442 \\
6,998 \\
941 \\
1,404 \\
657\end{array}$ & $\begin{array}{r}5,522 \\
9,058 \\
29,407 \\
4,707\end{array}$ & $\begin{array}{r}931 \\
3,147 \\
\end{array}$ & $\begin{array}{r}200 \\
22,455\end{array}$ & 11,640 & 1,370 & 770 & $\begin{array}{r}370 \\
1,497 \\
2,653 \\
5,735\end{array}$ & 347 & 1,547 & 3,928 & $\begin{array}{l}1,290 \\
5,153\end{array}$ \\
\hline Total & 35,494 & $11: 260$ & 34,909 & 20,173 & 32,376 & 27,5003 & 48,694 & 4,078 & 22650 & 11,640 & 1,370 & 8.59 & 10,432 & 347 & 1,547 & 3,928 & 6,442 \\
\hline$\%$ & $11.3 \%$ & 36,6 & $11.1 \%$ & $6.4 \%$ & $10.3 \%$ & $8.8 \%$ & $15.5 \%$ & $1.3 \%$ & $7.2 \%$ & $3.7 \%$ & $0.4 \%$ & $0.3 \%$ & $3.3 \%$ & $0.1 \%$ & 0.55 & $1.3 \%$ & $2.1 \%$ \\
\hline
\end{tabular}

\begin{tabular}{|c|c|c|c|c|c|c|c|c|c|c|c|c|c|c|c|c|c|c|}
\hline Frea(Hsient & $\begin{array}{c}18 \\
6\end{array}$ & $\begin{array}{l}19 \\
11\end{array}$ & $\begin{array}{l}\mathbf{2 0} \\
12\end{array}$ & $\begin{array}{c}21 \\
8\end{array}$ & 22 & $\begin{array}{c}23 \\
5\end{array}$ & $\begin{array}{l}24 \\
14\end{array}$ & $\begin{array}{c}25 \\
6\end{array}$ & $\mid \begin{array}{c}26 \\
1\end{array}$ & $\begin{array}{c}\mathbf{2 7} \\
3\end{array}$ & $\begin{array}{l}28 \\
11\end{array}$ & $\begin{array}{c}29 \\
5\end{array}$ & $\begin{array}{c}30 \\
6\end{array}$ & $\begin{array}{c}31 \\
7\end{array}$ & $\begin{array}{c}32 \\
4\end{array}$ & $\begin{array}{l}33 \\
11\end{array}$ & Total & $y_{10}$ \\
\hline $\begin{array}{l}\text { Taipei } \\
\text { Taoyuan } \\
\text { Hsinchu } \\
\text { Miaoli } \\
\text { Taichung } \\
\text { Changhwa } \\
\text { Nantou } \\
\text { Yunlin } \\
\text { Chiayi } \\
\text { Tainan } \\
\text { Kaohsiung } \\
\text { Pinglung } \\
\text { Taitung } \\
\text { Hwalien }\end{array}$ & 1,6655 & 2,187 & $\begin{array}{r}237 \\
9,646\end{array}$ & $\begin{array}{r}2,088 \\
457 \\
2.777 \\
1,045\end{array}$ & 503 & 2910 & 587 & 376 & $\begin{array}{l}2,973 \\
1,697\end{array}$ & 432 & $\begin{array}{r}3,7788 \\
173\end{array}$ & 187 & 38 & $\begin{array}{r}2,952 \\
544\end{array}$ & 291 & $\begin{array}{ll}1,701 \\
\end{array}$ & $\begin{array}{r}5,2014 \\
20,112 \\
7,430 \\
15,596 \\
7,794 \\
48,448 \\
3,883 \\
32,393 \\
21,752 \\
72,111 \\
22,473 \\
47,507 \\
3,928 \\
5,316\end{array}$ & 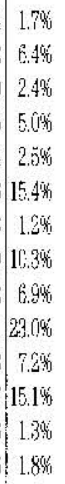 \\
\hline Total & 2,188 & & 9,882 & $6: 338$ & 503 & 200 & 587 & 376 & 6,346 & 432 & 4,145 & 187 & 38 & 4,983 & 291 & 1,701 & 314,94 & 1100 \\
\hline$\%$ & $0.7 \%$ & $0.7 \%$ & $3.1 \%$ & $20 \%$ & $0.2 \%$ & $0.1 \%$ & $0.2 \%$ & $0.1 \%$ & $2.0 \%$ & $0.1 \%$ & $1.3 \%$ & $0.1 \%$ & $0.0 \%$ & $1.6 \%$ & 0.15 & $0.5 \%$ & $109 \%$ & \\
\hline
\end{tabular}

Source: Taiwan Provincial Department of Agriculture and Forestry

The number from 1 to 33 represents the factories, here we do not include the name of factories (company) because of privacy.

t. The number in this raw indicates the area which factory is located in, and same as the number represented in the column of Area.

r The number of area from 1 to 4 indicates the north of Taiwan.

The number of area from 5 to 9 indicates the middle of Taiwan.

The number of area from 10 to 12 indicates the south of Taiwan.

The number of area from 13 to 14 indicates the east of Taiwan. 
depending on the season and the local demand. Therefore, we estimated the quantity for factories from number 1 to 7 in table 1 throughout the survey including phone call and data collected of Taiwan raw milk shipment quantity from supply counties to demand companies. We made phones calls to those biggest three companies of dairy division to inquire their raw milk distribution situation for their factories. For the company owning factory 1, 2, and 3 (as shown on table 1), its factory 1 located in Taipei processes raw milk shipped from the county of Taipei, Yunlin, and Tainan; factory 2 located in Yunlin processes raw milk shipped from the county of Kaohsiung; factory 3 located in Kaohsiung processes raw milk shipped from the county of Pingtung. For the company owning factory 4 and 5 (as shown on table 1), its factory 4 processes raw milk shipped from the county of Chiayi and Chiayi's north counties; its factory 5 processes raw milk shipped from Chiayi's south counties. For the company owning factory 6 and 7 (as shown on table 1), its factory 6 processes raw milk shipped from the county of Changhwa and Changhwa north counties; its factory 7 processes raw milk shipped from Changhwa's south counties. However, those three companies do not absolutely follow this regular rule of transportation routes. As above mentioned, they may adjust the processing quantity among those two or three factories depending on the season and the local demand.

\section{Taiwanese dairy industry}

Before the study of transportation problem in Taiwanese dairy industry, a brief introduction of that industry is useful. Although consumption of milk products are getting widespread in Taiwan, the relail prices of milk products are still high and 80 percent of raw inilk equivalent needs to be imported. Those imported dairy products are mainly composed of manufactured dairy products. While the raw milk production in Taiwan are mostly processed $65 \%$ for fresh drirking milk, $15 \%$ for flavored milk, $8 \%$ for long lift milk and $1 \%$ for fermented milk based on 1995 data. In figure 2 , it shows that the price constitutes of fresh drinking milk in each producing and marketing stage. The distribution proportion rate of raw milk for the season of winter, warm, and summer are $40 \%, 27 \%$, and $33 \%$, respectively. Thus, we calculate the raw milk price of $\$ 18.81 / \mathrm{kg}$. for the average factory purchase price of 1990 according to the rate. However, most factories need to pay subsidies of transportation fee to the dairy farmers and lake the risk of loss or spoiled, so we add $\$ 0.8 / \mathrm{kg}$. for those cosis which lead the tolal cost to $\$ 19.61 / \mathrm{kg}$. From the stage 2 to stage 3 , we estimated that the average processing cost is $\$ 9.59 / \mathrm{kg}$. based on the survey of factories, which we may consider it is so high to cover $33 \%$ of selling price out of factory $(9.59 / 29.2=33 \%)$. Moreover, we can tell that the marketing cost is quite high from the stage 3 to stage 6 which almost reaches 73 percent of a factory's material cost.

Based on the above analyses, it shows one feature of fresh drinking milk price constitution that each stage's cost seems very high. Especially, the purchase price of raw milk for factories is over $60 \%$ of factories' total cost. That is because Taiwanese government sets up the high guarantee purchase price for raw milk. Furthermore, the purchase price of raw milk through the negotiation of dairy farmers and factories becomes two dollars higher than before from June of 1997 due to global price increase of fertilizers and labor cost increase in Taiwan. The current imported dairy products of Taiwan are mainly composed of manufactured milk products, however, it will be asked to 


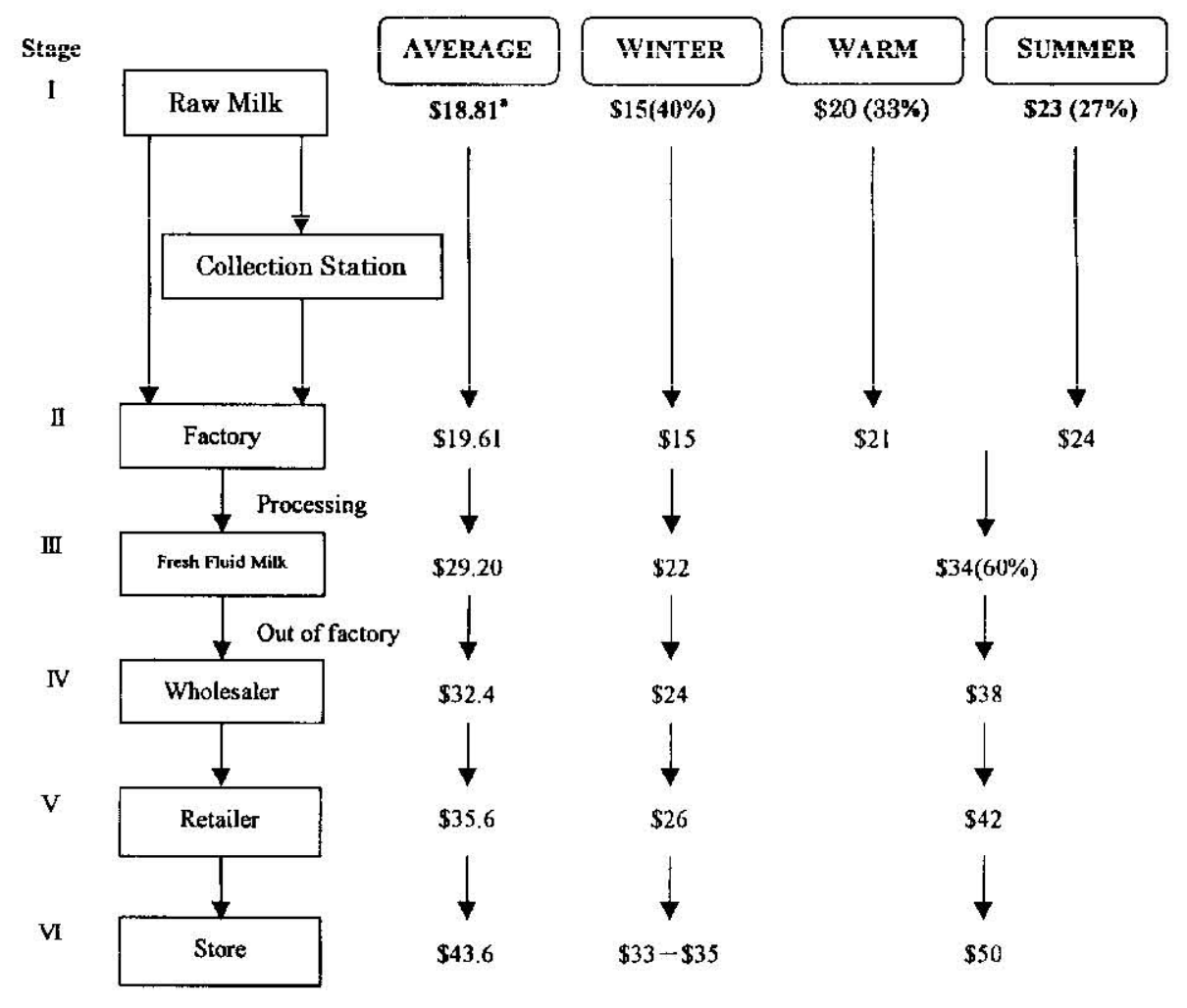

Unit: NT $\$ / \mathrm{kg}$.

Source: Taiwan Council of Agriculture, November 1991, based on 1990 data of milk factories Winter: Dec., Jan., Feb., Mar. Warm: Apr., May, Oct., Nov. Summer: Jun., Jul., Aug., Sept. (\%): proportion of milk quantity in that season to all of the year

"The purchase price becomes 2 dollars higher from June of 1997.

Fig. 2. Average price of fresh drinking milk in each producing and markcting stage in 1990

opon more market share for fluid milk including flavored milk, long lift milk and fermented milk when Taiwan becomes a member of WTO (World Trade Organization). (Lio, H. M. 1997) If the price of Taiwan milk products still continues to maintain in such high level, it may face the problem of competition with imported products in the near future due to an open market. Therefore, under the trend of liberalization and internationalization, Taiwanese dairy industry will be asked to reduce tariffs and trade 
subsidies, limit production quota, lower price support as well readjust dairy structure. Some dairy farmers may suffer from discontinuance of farm operation because of severe competitions.

On the other side, the cost of raw milk production compared with other countries seems too high (table 2). The environment of raw milk production in Taiwan is very close to Japan's. Table 3 tells us that the cost of fertilizes and wages holds obviously an important proportion. To reduce those costs is not an easy work, so the better way to solve the problem should be increasing the productivity in both countries. Some reasons causing low productivity, especially for Taiwan, are the weather, dairy farm operations and techonologies and etc.. It seems difficult to improve those factors not only because of the cost but also the uncontrollable natural conditions such as weather, location, and geographical features.

Table 2. Comparison of dairy related data among selected countries

\begin{tabular}{|c|c|c|c|c|c|c|c|}
\hline . & & $\begin{array}{l}\text { Number of } \\
\text { dairy farms }\end{array}$ & $\begin{array}{l}\text { Number } \\
\text { of cows }\end{array}$ & $\begin{array}{l}\text { Cows per } \\
\text { farm }\end{array}$ & $\begin{array}{l}\text { Total milk } \\
\text { production }\end{array}$ & $\begin{array}{c}\text { Milk per } \\
\text { cow }\end{array}$ & $\begin{array}{c}\text { Production } \\
\text { cost per } 100 \\
\text { kg. }\end{array}$ \\
\hline Country & Year & Number & $\begin{array}{l}1000 \\
\text { head }\end{array}$ & Number & 1000 ton & $\mathrm{kg}$. & US\$ \\
\hline Taiwan & 1995 & 968 & 66 & 69 & 318 & 4,788 & $47.52(100)$ \\
\hline Japan & 1994 & 48,000 & 1,247 & 26 & 8,388 & 6,726 & $64.95(80 \sim)$ \\
\hline German & 1993 & 275,000 & 5,293 & 17 & 34,097 & 6,314 & $38.94(200)$ \\
\hline America & 1994 & 148,690 & 9,525 & 64 & 80,322 & 8,433 & $28.08(172)$ \\
\hline England & 1989 & 47,000 & 2,933 & 62 & 16,822 & 5,854 & $23.62(207)$ \\
\hline New Zealand & 1994 & 14,649 & 2,831 & 193 & 12,057 & 4,259 & $15.01(181)$ \\
\hline
\end{tabular}

Source: Taiwan Council of Agriculture; The MAFF of Japan, Statistics of Livestock Products EC Dairy Facts \& Figures; Statistics New 7ealand, LIC; USDA Agricultural Statistics

Table 3. Composition of raw milk production cost. in Taiwan and Japan

\begin{tabular}{cccccccc} 
& & & & \multicolumn{2}{c}{ Unit: USS/per 100 kg. raw milk, \% } \\
\hline & Fertilizers & Wages & $\begin{array}{c}\text { Replacement } \\
\text { livestock }\end{array}$ & Interest & $\begin{array}{c}\text { Machine \& } \\
\text { facility } \\
\text { deprecialion }\end{array}$ & Others & Total \\
\hline Taiwan (1995) & 25.8 .3 & 6.34 & 5.72 & 2.59 & 2.44 & 4.6 & 47.52 \\
\% & 54.36 & 13.34 & 12.04 & 5.45 & 5.13 & 9.68 & 100 \\
Japan (1995) & 29.06 & 14.09 & 12.53 & 1.65 & 1.95 & 5.67 & 64.95 \\
\% & 44.74 & 21.69 & 19.29 & 2.54 & 3.00 & 8.73 & 100 \\
\hline
\end{tabular}

Source: Lui, Shoa Yin 1996 Booking analysis of dairy farm management in Taiwan. Taiwan Council of Agriculture

Tajwan Livestock Research Institute

The Ministry of Agriculture, Forestry and Fisheries of Japan, Statistics and Information Department 
In this paper, we will not discuss how to increase production or reduce the producing or marketing cost by changing any factors mentioned above. We would rather study how to lower the transportation cost of raw milk under current condition of its demand and supply. Thus, we only consider the stage of shipping raw milk from dairy farms to factories while ignoring processing stage and the procedure of shipping milk products from factories to retail stores, and test if current raw milk shipping system is under least transportation cost.

\section{THEORETICAL MODEL AND APPLICATION}

\section{Specification of theoretical model-classical transportation problem}

We specify the problem of determining the least cost solution for both of raw milk shipping quantity and shipping routes as classical transportation problem as follows.

$$
\text { Minimize } z=\sum_{i=1}^{m} \sum_{j=1}^{n} c_{i j} x_{i j}
$$

Subject to the following conditions:

$$
\begin{aligned}
& \sum_{j=1}^{n} x_{i j}=a_{i}, \quad i=1,2, \cdots, 14 \\
& \sum_{i=1}^{m} x_{i j}=b_{j}, \quad j=1,2, \cdots, 33 \\
& x_{i} \geqq 0, \quad i=1,2, \cdots, m ; \quad j=1,2, \cdots, n \quad \mathrm{~m}=14 \quad \mathrm{n}=33 \\
& \sum_{i=1}^{m} a_{i}=\sum_{j=1}^{n} b_{j} \quad \text { (total supply quantity =total demand quantity) }
\end{aligned}
$$

where

$$
\begin{aligned}
& c_{i j}: \text { unit transportation cost from supply area i to factory } \mathrm{j} \text { (table } 4 \text { ) } \\
& x_{i j}: \text { shipment quantity from supply area i to factory } \mathrm{j} \\
& a_{i}: \text { supply quantity of area i shown in table } 1 \text { (total of raw } \mathrm{i} \text { ) } \\
& b_{j}: \text { demand quantity of factory j shown in table } 1 \text { (total of column } \mathrm{j} \text { ) }
\end{aligned}
$$

The table 4 indicates the unit raw milk transportation cost between supply areas and factories by milk tank lorries. Actually, it is very difficult to collect the data of transportation fee between all of the factories and dairy farms. As a result, we did the survey for some companies or factories to calculate the average unit raw milk transportation cost. The amount of the subsidies of raw rnilk transportation cost which factories pay to dairy farmers is based on the distance. The unit raw milk transportation cost is NT $\$ 0.4 / \mathrm{kg}$. for distance under 50 kilometer $(\mathrm{km}),. \$ 0.65 / \mathrm{kg}$. for distance from $51 \mathrm{~km}$. to $100 \mathrm{~km}$., $\$ 0.9 / \mathrm{kg}$. for the distance from $101 \mathrm{~km}$. to $150 \mathrm{~km}$., $\$ 1 / \mathrm{kg}$. for distance from $151 \mathrm{~km}$. to $200 \mathrm{~km}$., $\$ 1.2 / \mathrm{kg}$. for distance from $201 \mathrm{~km}$. to $250 \mathrm{~km}$., and $\$ 1.4 / \mathrm{kg}$. for distance over $250 \mathrm{~km}$.

\section{Optimal solution of the transportation problem and its implication}

We solved the classical transportation problem specified above by linear programming 
Table 4. Unit of raw milk transportation cost in 1996

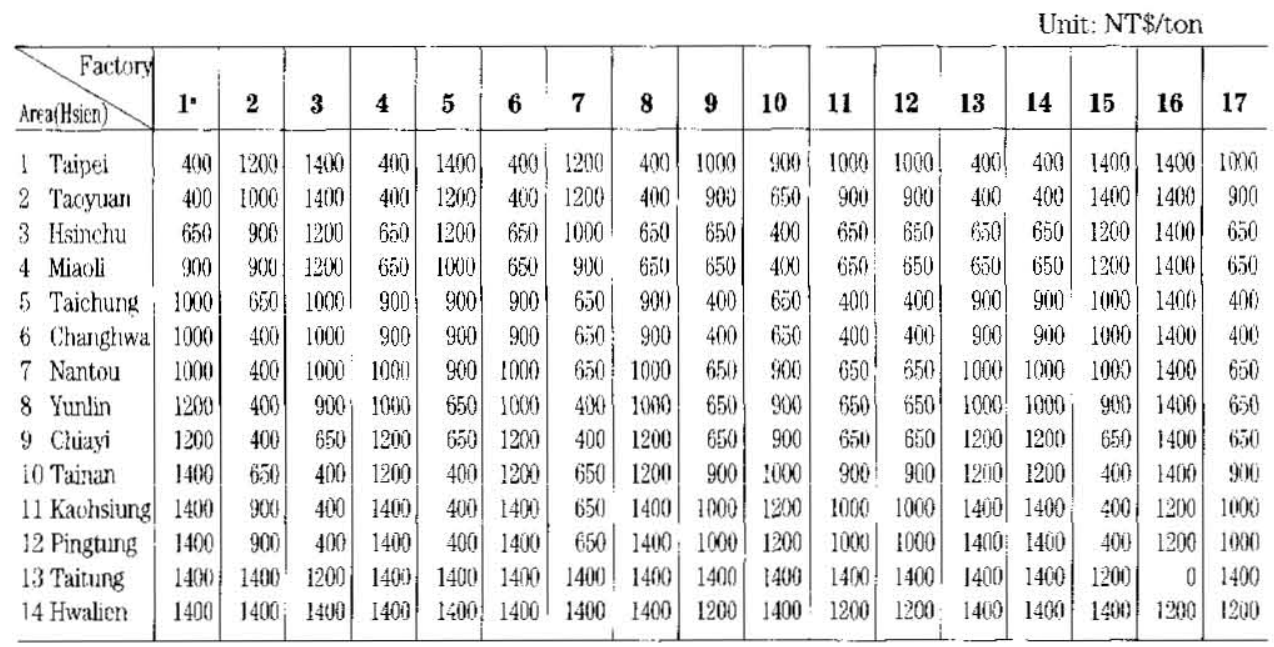

\begin{tabular}{|c|c|c|c|c|c|c|c|c|c|c|c|c|c|c|c|c|}
\hline Arca(Hsiegl) & 18 & 19 & 20 & 21 & 22 & 23 & 24 & 25 & 26 & 27 & 28 & 29 & 30 & 31 & 32 & 33 \\
\hline 1 Taipei & 1000 & 1400 & 1400 & 120 & 2400 & 19000 & 1400 & 1000 & 400 & 650 & 1400 & 1000 & 10000 & 1000 & 9001 & 1400 \\
\hline 2 Taoysuan & 990 & 1400 & 1400 & 1000 & 1400 & 900 & 1400 & 900 & 400 & 650 & 1400 & 900 & 9019 & 1000 & (50) & 1400 \\
\hline 3 Hsinchu & 650 & $1: 200$ & 1200 & 90 & 1400: & 550 & 1400 & 650 & $65 i j$ & 400 & 1206 & 650 & 650 & 980 & 400 & 1200 \\
\hline 4 Miaoli & 60.9 & 1200 & 1200 & 900 & 1400 & 650 & 1400 & 65,50 & $3(0)$ & 400 & 1200 & 65i) & 6500 & 300 & $400^{\circ}$ & $1210\}$ \\
\hline ¿ Taichung & 400 & 1000 & 1000 & 6.50 & 1200 & 400 & 1200 & 400 & 1000 & 6,50 & 1000 & 400 & $400 \mathrm{i}$ & 650 & 650 & 1000 \\
\hline 6 Changhwa & 400 & 1000 & 1000 & 400 & 1400 & 400 & 1400 & 400 & 1000 & 650 & $1000 ?$ & 400 & $400 !$ & 0 & 650 & 1000 \\
\hline 7 Nantou & 650 & 1000 & 1200 & 4005 & 1400 & 650 & 1400 & 650 & 1000 & 9001 & 1000 & 650 & $6500^{\circ}$ & 400 & $300 !$ & 1600 \\
\hline 8 Yunlin & 400 & 900 & 900 & 400 & 1400 & 650 & 1400 & 400 & 1200 & 900 & 900 & 60 & 400 & 400 & $937=$ & 940 \\
\hline 9 Chiayi & 650 & 650 & 650 & 400 & 1400 & 650 & 1400 & f5010 & 1200 & 1000 & 6.50 & 650 & 650 & 550 & 900 & 650 \\
\hline 10 Tainan & 900 & $4(x)$ & 400 & 606 & 1400 & 900 & 1400 & 900 & 1400 & 1260 & 400 & 900 & $\$ 00$ & 900 & 1000 & 400 \\
\hline 11 Karhssiung & $1(1000$ & 400 & 400 & 900 & 1200 & 1000 & 1200 & 1000 & 1400 & 1200 & 400 & $I(0) 10$ & 10010 & $1600)$ & 12100 & 400 \\
\hline 12 Pingtung & 1000 & 400 & 409 & 900 & 1200 & 1000 & 1200 & 1000 & 1400 & 1300 & 400 & 1000 & 1000 & 1200 & $130:$ & 400 \\
\hline 13 Taiturg & 1400 & 1200 & 12100 & 1400 & 1200 & 1400 & 1200 & 14100 & 1400 & 1400 & 1200 & 1400 & 1400 & 1400 & 1400 & 1200 \\
\hline 14 Hwahen & 1400 & 1450 & 1400 & 1400 & 0 & 1260 & 0 & 1400 & 1400 & 1400 & $1400)$ & 1200 & 1400 & 1400 & 1400 & 1400 \\
\hline
\end{tabular}

Source: 1998 Taiwan Walking Internct, for data of road distances

The data of unit transportation cost is through factories survey.

a The number from 1 to 33 represents the factories, here we do not include the name of factory (company) because of privacy.

When the factory is in the sarre place of supply area (factory owns its own dairy farms) we consider that the unit raw milk transportation cost is " 0 ". 
method, and the results are shown in table 5 with the related data, indicating the optimum routes and quantity. The all transportation routes have a lot of change comparing in both of table 1 and table 5 . The number of transportation routes in table 1 is 69 and it shifts to 45 in table 5 excluding one route which quantity is zero, which means it simplifies the transporting method for the whole milk industry under the optimal solution of least transportation cost.

It should be noted here that optimal solution of classical transportation problem is usually not unique. We can usually find many sets of optimal solutions. For example, all of the following sets of solutions are optimal.

$$
\begin{array}{lll}
x_{11}=3284+\alpha & x_{1,26}=1920-\alpha & \\
x_{21}=20112-\alpha & x_{2,26}=\alpha & 0 \leq \alpha \leq 1920 \\
x_{51}=595-\beta & x_{: 9}=\beta & \\
x_{61}=190+\beta & x_{69}=22655-\beta & 0 \leq \beta \leq 595 \\
x_{62}=\gamma & x_{87}=18416-\gamma & \\
x_{10,2}=11260-\gamma & x_{10,7}=8526+\gamma & 0 \leq \gamma \leq 11260
\end{array}
$$

the values of other $450(=33 \times 14-12) x_{i j}$ are as same as that in table 5

We can change the value of parameters $\alpha, \beta, \gamma$ and adjust the quantity of each route withont changing total transportation cost. Thus, we can find infinite number of optimal solutions. If the value of $\beta$ increases, the transportation cost of area 5 will reduce and it will increase in area 6 . In addition, if the value of $\gamma$ increases, the transportation cost of factory 2 will reduce and it'll increase in factory 7 . Thus, it is obvious that the transportation costs for each factory are usually different depending on the optimal solution used.

\section{RESULTS AND DISCUSSION}

The delivery routes and quantities of raw milk is determined by individual company and dairy farmers with the contracts, with support and supervision from the government, Taiwan Provincial Department of Agriculture and Forestry. First of all, the government determines the standard raw milk price based on the production cost of raw milk. In addition, the factory pays the amount to dairy farmers based on the standard price and adjusts it according to the raw milk quality. (Lio, Y. C. 1996)

Based on the data in table 1 and table 4, we can calculate the total current transportation costs, equal to $198,812,230$ NT dollars (about 7,231,902 US dollars). Furthermore, the total transportation costs decrease to $178,786,550$ NT dollars after applying the optimum routes. It means that the total raw milk industry can save about 10 percent of transportation costs if the raw ruilk delivering system is according to optimum routs.

The problem here is how to create an improved system to reach the goal of least transportation cost. According to table 5, some factories show an increase of transportation costs, but the others show a decrease. Nevertheless, the whole milk industry can save about 10 percent of transportation cost by utilizing the optimum routes in table 5 . There is one possible method to allocate those 10 percent save to each 
Table 5. Optimal solution of the transportation problem and related data

Unit of quantity: ton

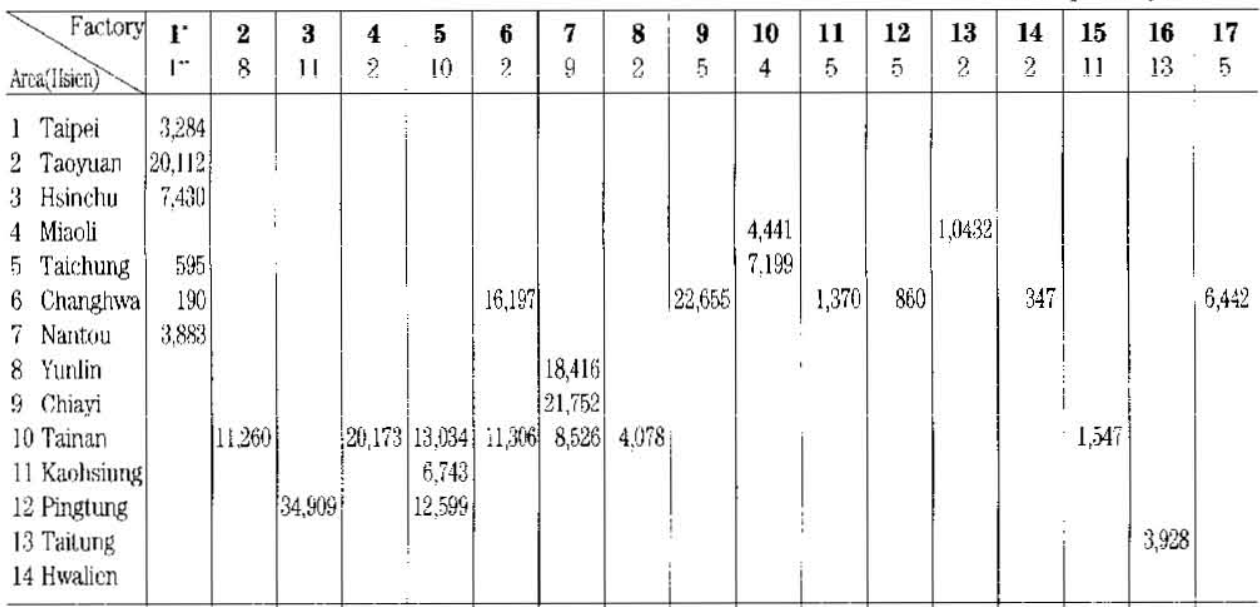

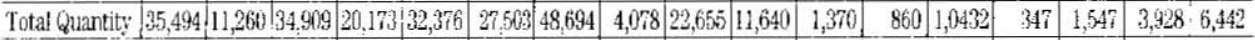

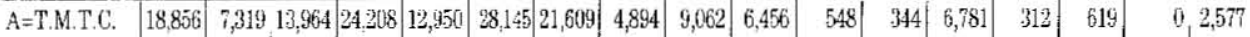

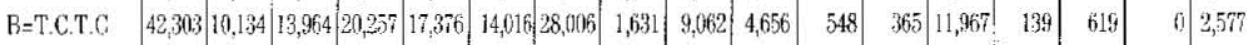

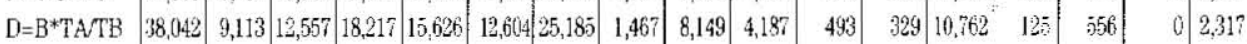

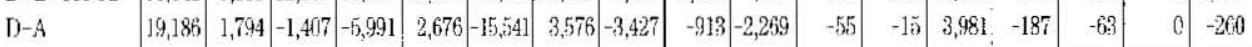

\begin{tabular}{|c|c|c|c|c|c|c|c|c|c|c|c|c|c|c|c|c|c|}
\hline Factory & $\begin{array}{c}18 \\
6\end{array}$ & $\begin{array}{l}19 \\
11\end{array}$ & $\begin{array}{l}20 \\
12\end{array}$ & $\begin{array}{c}21 \\
8\end{array}$ & $\begin{array}{l}22 \\
14\end{array}$ & $\begin{array}{c}23 \\
5\end{array}$ & $\begin{array}{l}24 \\
14\end{array}$ & $\begin{array}{c}25 \\
6\end{array}$ & $\begin{array}{c}26 \\
1\end{array}$ & $\begin{array}{c}27 \\
3\end{array}$ & $\begin{array}{l}28 \\
11\end{array}$ & $\begin{array}{c}29 \\
5\end{array}$ & $\begin{array}{c}30 \\
6\end{array}$ & $\begin{array}{c}31 \\
7\end{array}$ & $\begin{array}{c}32 \\
4\end{array}$ & $\begin{array}{l}33 \\
11\end{array}$ & Total \\
\hline $\begin{array}{ll}1 & \text { Taipci } \\
2 & \text { Tanyuan } \\
3 & \text { Hsinchu } \\
4 & \text { Miaoli } \\
5 & \text { Taichung } \\
6 & \text { Changhwa } \\
7 & \text { Nantou } \\
8 & \text { Yurlin } \\
9 & \text { Chiayi } \\
10 & \text { Tainan } \\
11 & \text { Kanhsiung } \\
12 & \text { Pingtung } \\
13 & \text { Taitung } \\
14 & \text { Hwalien }\end{array}$ & 2,188 & 2,187 & 9,884 & 5,338 & 503 & 200 & 587 & 376 & $\begin{array}{r}0 \\
4426\end{array}$ & 432 & 4,140 & 187 & 38 & 4,983 & 291 & 1.701 & $\begin{array}{r}5,204 \\
20,112 \\
7,430 \\
15,396 \\
7.794 \\
48,448 \\
3,883 \\
32,339 \\
21,752 \\
72,111 \\
22,473 \\
47,508 \\
3,928 \\
5,716\end{array}$ \\
\hline Total Quantity & 2,188 & 2,187 & 9,834 & 6338 & 503 & 200 & 587 & 376 & 6.346 & 432 & 4.145 & 187 & 38 & 4,983 & 291 & 1,701 & 314,094 \\
\hline $\mathrm{A}=\mathrm{Y}$.M.T.C. & 875 & 875 & $3,9,4$ & 2,335 & 0 & 80 & 0 & 150 & $6: 964$ & 173 & 1658 & 75 & 15 & 1,993 & 116 & 680 & 178.787 \\
\hline B=T.C.T.C & 1,006 & 875 & 3,953 & 2,535 & 0 & 130 & 1) & 151 & 6.297 & 173 & 1,712 & 75 & 15 & 3,474 & 116 & 680 & 198,812 \\
\hline D-B*TA/TB & 905 & 787 & 3,55 & 2,280 & a) & 117 & (1) & $1: 35$ & 5,662 & 155 & 1,539 & 67 & 14 & 3,124 & 105 & 612 & 178,788 \\
\hline$D-A$ & 30 & -88 & -399 & -255 & 0 & 37 & B) & 15 & $-1,302$ & -18 & -119 & -8 & -1 & 1,131 & -11 & -68 & \\
\hline
\end{tabular}

*,** the number indicates are same as the rumber in table 1

Lnit of $A, B$, and D is NT $\$ 1,000$

$A=$ T.M.C.=total minimum transportation cost of each factory

$B=$ T.C.T.C. $=$ total current transportation cost of each factory

$\mathrm{D}=\mathrm{B} \times$ Total of $\mathrm{A} / \mathrm{T}$ tal of $\mathrm{B}=\mathrm{B} \times(178,787 / 198,812)$

$\mathrm{D}-\mathrm{A}=$ Difference amount which each factsry should pay (when $\mathrm{D}-\mathrm{A}$ is positive) or receive (when

D $A$ is negative) 
factories as the follow.

\section{Approach system applied to the practice}

First, we calculate 90 percent of original transportation cost for each factory (we can get this figure $89.93 \%$ by computing least transportation cost divided by total current transportation cost showed in table 5), then figure out every factory's difference (in table 5 indicated in row of " $\mathrm{D}-\mathrm{A}$ ") between $90 \%$ of its original transportation cost and transportation cost under optimum routes. If the difference of some factory turns out to be positive, it means efficiency under optimum system for this factory. This factory can also offer the difference amount to the factories which difference are negative. Otherwise, the factories with negative difference can receive difference payments. Finally, every factory can save 10 percent of transportation costs if the system can be operated effectively. The only way is that all of factories need to cooperate well with each other to adjust their transportation routes and to allocate the difference payment rationally.

\section{CONCLUSION}

We specified the classical transportation problem to find out the least cost solution for both raw milk shipping quantity and shipping routes in Taiwan. We also illustrated how to effectively implement the least cost solution. In this case, dairy industry in Taiwan can save about 10 percent of raw milk transportation cost under least cost solution. To reach the goal, we need to create an appropriate system to allocate those 10 percent save to each factory and areas for implementing the least cost efficiently. Otherwise, we will not be able to realize those 10 percent save without organizing appropriate system to allocate it effectively.

According to the similar studies in .Japan, they show that Japan dairy industry will be able to save about 11.9 percent of raw milk transportation cost in September 1995, 17.1 percent in November 1996, and 28.8 percent in December 1996 (Kawaguchi, 1997), if the least cost solutions of transportation problems are practiced effectively by appropriate systems to allocate those saves.

There are still some problems cannot be overcome in our study. For example, in this case we assume all of transportation fee are paid by the factories, but actually some factories pay only part of it. Another problem is regarding the method of distance measurement, in this study we use the length of highway to measure the distance between two area (Hsien). For that reason, it may be a little different from the actual driving distance. In such cases, we need to use other appropriated method to allocate those 10 percent save to each factory and to each areas. We will try to measure the actual driving distance to improve our analyses in future study.

The most important remark to make about this paper's model is that we specified the model in short-run under the assumption of given demand and supply. However, both demand and supply may vary in the long-run following the price change and other related changes. Therefore, in next paper, we are going to discuss the spatial equilibrium in the long-run and to find out the equilibrium solutions for each supply area and each factory demand as well as equilibrium prices. 


\section{REFERENCES}

Japan Dairy Council 1997 1995-1996 Report of simulation analysis on Japan raw milk delivery surveys (in Japanese)

Lio, Huei Ming 1997 The introduction of producing and marketirug situation ir Taiwanese fluid milk industry. Food Markeling News, July 1997, Taiwan 8607: 10-12

Lio, Yao Chung 1996 An economic analysis of dairy farmer's milk production cost in Taiwan. MA Thesis. National Chung Hsing Universily, Taiwan 